\title{
MARKET REACTION ON THE ANNOUNCEMENT OF SRI KEHATI INDEX IN INDONESIAN STOCK EXCHANGE
}

\author{
Anggita Langgeng Wijaya \\ Universitas PGRI Madiun, Kota Madiun, Indonesia \\ gonggeng14@gmail.com \\ Mia Noviyanti \\ Universitas PGRI Madiun, Kota Madiun, Indonesia \\ mianoviyanti18@gmail.com \\ Probo Mahayu \\ Universitas PGRI Madiun, Kota Madiun, Indonesia \\ pmahayu@gmail.com
}

\begin{abstract}
The purpose of this study was to test the market reaction to the announcement of the Sri Kehati Index on the Indonesia Stock Exchange. The population in this study is all companies included in the Sri Kehati Index from 2013 to 2016. The selection of samples was taken by the population sampling method. Hypothesis testing is done by paired t test and Wilcoxon Signed Rank Test. The findings of this research are: 1) there is no difference in abnormal returns before and after the announcement of the Sri Kehati Index on the Indonesia Stock Exchange. 2) There is a difference in the activity of stock trading volume before and after the announcement of the Sri Kehati index in the 5th and 6th periods, but there is no difference in the activity of stock trading volume in other periods. The Indonesia Stock Exchange did not react consistently to the announcement of the Sri Kehati Index.
\end{abstract}

\section{Keywords}

Market Reaction; Sri Kehati Index; Corporate Social Responsibility; Abnormal Return; Trade Volume

\section{JEL Classification}

M40; M14

\section{Introduction}

This research aims to examine the reaction of the Indonesian capital market to the announcement of the Sri Kehati Index in the observation period from 2013 to 2016. The Sri Kehati Index is a kind of stock index on the Indonesia Stock Exchange that provides an assessment to companies that have investments and businesses that are oriented to environmental, social, humanitarian concerns and the utilization and preservation of biodiversity. The Sri Kehati Index was formed by the authorities of the Indonesia Stock Exchange and the Indonesian Biodiversity Foundation on June 8, 2009 (Lindananty \& Soedarman, 2015). The concept of valuation of the company's stock index Sri Kehati is in line with the concept of corporate social responsibility.

Wang et al (2016) explained that the concept of corporate social responsibility begins with the idea that businesses have a responsibility to the community and all stakeholders who are directly or indirectly involved in the company. Since the 1960s, the concept of corporate social responsibility has attracted so much attention from academics and practitioners. Although the idea of CSR has received various criticisms, research on CSR has been growing very dynamically.

Reddy and Kala (2018) stated that CSR shows organizational commitment in balancing efforts to achieve business profits with social interests to employees, local communities 
and society. According to Cheng and Setiawan (2011), the implementation of CSR in the company's strategy and operations will get investors' attention. Companies that implement good CSR policies show that companies prioritize business sustainability and environmental problems. Investors are expected to tend to invest in companies that have good CSR. CSR can be a strategy to demonstrate the company's competitive advantage. Wang et al (2016) states that the implementation of CSR is related to value creation activities.

The Government of the Republic of Indonesia also pays attention to the implementation of CSR. Through Law No. 40 of 2007 concerning incorporated companies, the Government of the Republic of Indonesia requires companies in the natural resource industry to carry out and report CSR activities. The Indonesian Stock Exchange Authority then issued a measurement of the level of company concern for CSR and the environment in the form of a stock index. The Indonesia Stock Exchange in collaboration with the Biodiversity Foundation launched a stock index called the Sri Kehati Index.

Sri Kehati Index is a stock index which is calculated from companies that are considered to have very good attention to the environment, social and humanity. Sri Kehati Index consists of 25 companies in the Indonesia Stock Exchange. The Sri Kehati Index is announced twice a year in April and October. The composition of companies included in the Sri Kehati index is possible to differ during each announcement.

Indahyanti and Wijaya (2014) revealed that one of the objectives of financial reporting is to provide information that is useful to users of the report. Carnevela et al (2012) states that accounting information is has value relevance if the information can affect the market equity value. Previous research shows that accounting information alone cannot explain variations in equity market values. The influence of non-financial information on the value of equity raises a lot of debate among academics. According to Carnevela et al (2012), research on the influence of CSR information on the capital market becomes interesting to analyze. The existence of the Sri Kehati stock index on the Indonesia Stock Exchange is expected to provide investors with additional nonfinancial information about the company's social responsibility.

Market reaction to announcements or information on the market can be evaluated from changes in stock prices and stock trading volume activities (Wijaya \& Sudana, 2017). Stock trading volume is able to describe investor expectations on new information, while changes in stock prices indicate the influence of information at the market level (Beaver, 1968). Stock trading volume is able to reflect investor activity because it considers every action taken by the investor through the sum of all stock trading, while the price reflects an aggregation or average of investor confidence (Wijaya \& Sudana, 2017).

According to Halkos and Sepetis (2007), the stock market evaluates the stock market value of Greek companies that implement environmental management systems. Company policies that are oriented to environmental concerns require large costs. The capital market should be able to provide a different response between companies that have good environmental performance and poor environmental performance. This study concludes that a better environmental management system results in a reduction in company risk. In the Indonesian capital market, one indicator of environmental performance is the Sri Kehati index. According to Zufkafli et al (2017), the Sri Kehati index is an index that shows that the company has considered social investment and responsible environmental management.

Previous research on the Sri Kehati index in the Indonesia Stock Exchange has produced inconsistent results. Lindananty and Soedarman (2015) state that there is no reaction to the issuance of the Sri Kehati Index when measured by abnormal returns, however, the results are different when measured by trading volume activity. This means that the market reaction is not consistent with the Sri Kehati index information. 
Asmara (2017) stated that the capital market will react to the disclosure of social responsibility in companies included in the Sri Kehati index.

Based on the inconsistencies of several previous studies, the researchers considered that research on the reaction of the Indonesian Stock Exchange to the Sri Kehati index needed to be re-examined as an effort to complement previous research regarding the capital market reaction to the Sri Kehati index.

The next part of this study will be presented as follows: The second part contains a literature review and development of hypotheses, the third section describes the research method, the fourth section discusses the research analysis, the fifth section presents the research discussion and the last section discusses conclusions, limitations and research suggestions.

\section{Literature Review and Hypotheses Development}

\section{Corporate Social Responsibility}

Malik and Kanwal (2018) explain that CSR is not a new concept. The definition of CSR at the beginning was the management of business organizations and social performance that had a positive impact on the community. Becchetti et al (2014) explained that CSR has shifted the company's efforts to maximize profits on more complex business strategies in order to satisfy various stakeholders. Companies in an effort to achieve profits, companies must be able to properly consider the impact of business activities on the interests of each of the stakeholders. Cahan et al (2016) explained that CSR will have an impact on the company's reputation, a greater goodwill of the company and an increase in the company's performance in the long run. Previous research has explained that the company's social performance has an impact on the company's financial performance.

Ksiezak and Fischbach (2017) stated that CSR is the way the company is responsible for the company's stakeholders. The importance of CSR for corporate strategy is closely related to the company's stakeholders. Companies need trust and good relationships with suppliers, business relations, employees and other social organizations. According to Ksiezak and Fischbach (2017), the basic concept of CSR refers to three basic pillars, namely profit, people and planet. The profit aspect will relate to multiplayer effects, taxation and activities that can damage trust in the company. Aspects of people include the responsibility of the consumer company, responsibility for employees and responsibility for the community. The planetary aspect includes the company's concern for business activities that affect the natural environment.

Wang and $\mathrm{Li} \mathrm{(2016)}$ state that increasing global attention and concern for CSR has made a significant increase in corporate CSR reporting worldwide. Astuti and Nugrahanti (2005) explained that investors not only analyze earnings information, but also evaluate the disclosure of corporate social and environmental responsibilities. Reporting and disclosure of CSR activities is one way to send signals to stakeholders (investors) and the market. CSR disclosure is expected to provide a signal that can increase the value of the company. Stakeholders are expected to have a positive perception of companies that implement CSR strategies well and have an interest in investing in the company.

Wang and $\mathrm{Li}$ (2016) stated that CSR disclosure provides added value for information users to assess the risks and performance of the company in the future. According to Lopatta et al (2016), research on CSR still causes a lot of debate. Academics and practitioners are considered not to agree about the definition and interpretation of CSR so that the results of research are still very varied. There is also no consensus of direct CSR benefits for companies such as reducing company costs and risks as well as indirect benefits in terms of competitive advantage. The existence of the Indonesian 
Stock Exchange's authority policy regarding the establishment of the Sri Kehati stock index is an opportunity to develop research on CSR.

\section{Sri Kehati Index}

The Sri Kehati stock index cannot be separated from the CSR concept. The Sri Kehati Index is the result of collaboration between the Biodiversity Foundation (Kehati Foundation) and the Indonesian Stock Exchange authorities. The word SRI stands for "Sustainable and Responsible Investment". Sri Kehati Index aims to provide additional information for investors about companies that have very good performance in terms of sustainable business, a good corporate governance system, and concern for the environment. This index assesses companies that have implemented CSR by considering six fundamental aspects as ranking criteria, including: environment, community development, corporate governance, human rights, business behavior and employment principles (Kehati.or.id, 2015).

The Sri Kehati Index consists of 25 company shares selected through a selection and ranking process. Based on the explanation presented on the Indonesia Stock Exchange website (https://www.idx.co.id/), the criteria used to conduct the assessment include: 1) the company has total assets above $\mathrm{Rp} 1$ trillion based on audited financial statements. 2) the company has a positive Price Earnings Ratio (PER). 3) Public share ownership is greater than $10 \%$. The next step is to choose the 25 best stocks by considering 6 main factors, which include: 1) Environment; 2) Community; 3) Corporate Governance; 4) Human Rights; 5) Business Conduct; 6) Employment Practices \& Decent Work. Companies registered in the shares of the Sri Kehati Index can change each announcement date.

The Indonesian capital market reaction to information will be indicated by changes in the company's stock price. Changes in stock prices on the stock exchange can be seen from changes in abnormal returns (AR), which is a comparison between actual returns and expected returns (Lindananty \& Soedarman, 2015). Market reaction can also be seen from the Trading Volume Activity (TVA). TVA measures a stock trading activity that occurs in a certain period which is calculated by comparing the volume of shares traded with the volume of previous shares. The capital market reaction to the Sri Kehati Index on this research will be seen from changes in abnormal returns and the company's Trading Volume Activity (TVA).

\section{Hypothesis Development}

Du et al (2017) explains that there is an increase in demand from the capital market for sustainability reports. The results of academic research show that sustainability reports affect firm value. Companies use various methods in communicating information about sustainability reports, for example through advertising, disclosure of information through annual report or company websites. Halkos and Sapetis (2007) explain that capital markets react to information about corporate environmental policies in which improving environmental performance will reduce the risk of the company.

Research on market reactions to social and environmental activities was carried out by Ramiah et al (2013). This study investigated the impact of 19 announcements on environmental regulations on entities listed on the Australian Stock Exchange during the period 2005-2011. The results showed that there was an abnormal return of $31 \%$ in the alternative energy sector which indicated that the environmental policy had an impact on the long-term energy sector industry. Atiqoh (2016) found that CSR disclosure affects company stock returns. However, other studies such as Astuti and Nugrahanti (2015) did not find the effect of corporate social responsibility on abnormal returns.

Research on Sri Kehati index has been done by some previous research. The research of Lindananty and Soedarman (2015) examined the consistency of Indonesian Stock 
Exchange reaction to the issuance of Sri Kehati index. The results were shown that for the reaction test of the Sri Kehati index announcement, it gives consistent result for nine periods the measurement of the abnormal return but does not yield consistent results when the market reaction was measured by trading volume activity. Indonesian Stock Exchange investors do not react consistently to the Sri Kahati Index announcement.

Kusumaningtyas and Andayani (2015) conducted a study on the effect of corporate governance on firm value on the company share that listed on the Sri Kehati Index. The results of this study was indicated that institutional ownership affects the value of the company while managerial ownership, the composition of independent commissioners and audit quality does not affect the value of the company in the company listed in the Sri Kehati index. Laurensia (2015) was conducted a study on the effect of financial performance on stock prices of companies included in Sri Kehati index by considering aspects of CSR disclosure. This study found the influence of financial performance on CSR but did not find the effect of financial performance and CSR on stock price of company. Zulkafli et al (2017) conducted a study on the comparison of stock portfolio performance between companies in Sri Kehati Index and Jakarta Composite Index. The results were shown that the company's stock performance included in Sri Kehati Index has a better portfolio performance than the company that listed the Jakarta Composite Index.

Previous research regarding the market reaction to the announcement of the Sri Kehati index has shown different results. If information about the Sri Kehati index is assessed by the market as good information, the capital market is expected give a good response. Sri Kehati is a CSR-based and sustainable investment index, so researchers suspect that the Indonesian capital market will react to the announcement of the index which can be observed from changes in abnormal returns and trading volume activity.

Based on the things mentioned above, the hypothesis in this study was expressed as follows.

$\mathrm{H}_{1} \quad$ : There are differences in abnormal return before and after announcement of Sri Kehati Index in Indonesian Stock Exchange

$\mathrm{H}_{2}$ : There are differences in trading volume activity before and after announcement of Sri Kehati Index in Indonesian Stock Exchange

\section{Research Methods}

\section{Data, Population and Sample}

This type of research is an event study, which uses window 10 for the data collection range ( 5 days before and 5 days after). Event studies are a type of study used to assess the impact of an event or certain information on the value of the company. The population in this study was all companies included in the 25 Sri Kehati index companies in the period 2013 to 2016. The sampling technique used was population samples. Data is obtained through the announcement of the Indonesia Stock Exchange data and daily stock price data on the yahoofinance.com.

\section{Definition and Measurement of Research Variables}

The capital market reaction in this study is as follows:

1. Abnormal Return (AR)

Abnormal Return is the difference between the actual return occurs with the return was expected investors. Abnormal Return measurement was used market adjusted model which is model which assumes that best estimator to estimate return of stock is market 
return index at that time (Lindananty and Soedarman, 2015). The used of this model will cause a stock return that is estimated to be the same as the market index return.

$$
A R_{i t}=R_{i t}-E\left(R m_{t}\right)
$$

Where,

$$
\begin{array}{ll}
\text { ARit } & =\text { Abnormal stock return of } \mathrm{i} \text { in period of } \mathrm{t} \\
\mathrm{R}_{\mathrm{it}} & =\text { Return of stock of } \mathrm{i} \text { in period of } \mathrm{t} \\
\mathrm{E}\left(\mathrm{Rm}_{\mathrm{t}}\right) & =\text { Expected return of stock market index in period of } \mathrm{t}
\end{array}
$$

The calculation of market index return used the following formula:

Where,

$$
E\left(R M_{t}\right)=\frac{I H S G_{t}-I H S G_{t-1}}{I H S G_{t}}
$$

$$
\begin{array}{ll}
\mathrm{E}\left(\mathrm{Rm}_{\mathrm{t}}\right) & =\text { Expected return of stock market index in period of } \mathrm{t} \\
\mathrm{IHSG}_{\mathrm{t}} & =\text { Composite Stock Price Index in period of } \mathrm{t} \\
\mathrm{IHSG}_{\mathrm{t}-1} & =\text { Composite Stock Price Index in period of } \mathrm{t}-1 .
\end{array}
$$

2. Trading Volume Activity (TVA)

Trading Volume Activity (TVA) is a stock trading activity that occurs in a certain period calculated by comparing the volume of stock (number of stock) traded with the volume of stock outstanding.

$$
T V A_{i t}=\frac{\sum \text { Stock } i \text { in period of } t-\text { Stock } i \text { in period of } t-1}{\sum \text { Stock } i \text { in period of } t-1}
$$

The Sri Kehati Index is annually announced twice in April and October. Announcement of Sri Kehati Index in the period 2013 to 2016 there are eight dates of Sri Kehati index announcement so that paired sample test was conducted for eight of the date of the announcement.

\section{Data Analysis Technique}

Data analysis in this study was carried out using a paired sample $t$ test. If the results of the data normality test show that the data is normally distributed, hypothesis testing will be carried out by paired samples $t$ test. However, if the data does not meet the normality assumption, hypothesis testing will be done with the Wilcoxon Signed Rank Test

\section{Analysis and Discussion}

In this section we will explain the results of the analysis of the Indonesian capital market reaction to the announcement of the Sri Kehati index. To facilitate the readers' understanding of this analysis, we explained that during the 2013-2016 research period there were 8 announcements of the Sri Kehati index on the Indonesia Stock Exchange. At each announcement of the Sri Kehati index there are potential changes in company data including the Sri Kehati index.

The Indonesian capital market reaction to the announcement of the Sri Kehati index will be seen from changes in the abnormal return and trading volume activity. If there is a difference of abnormal return and trading volume activity before and after announcement, it was indicated the market reaction, but if there is not difference indicated that capital market does not give response to Sri Kehati index announcement. Analysis of the market reaction is tested for each date index announcement. The table below shows in detail the date of the announcement of the Sri Kehati Index on the Indonesia Stock Exchange. 
Table 1 Period of Research Observation

\begin{tabular}{|c|c|c|c|}
\hline \multirow{2}{*}{$\begin{array}{l}\text { Observation } \\
\text { Period }\end{array}$} & \multicolumn{3}{|c|}{ Event Window } \\
\hline & $t-5$ & $t$ & $t+5$ \\
\hline 1 & $\begin{array}{c}\text { April } 22 \text { - April 26, } \\
2013\end{array}$ & April 29, 2013 & $\begin{array}{c}\text { April } 30 \text { - May 4, } \\
2013\end{array}$ \\
\hline 2 & $\begin{array}{c}\text { October } 23 \text { - October } \\
29,2013\end{array}$ & October 30, 2013 & $\begin{array}{c}\text { October } 31 \text { - } \\
\text { November 6, } \\
2013\end{array}$ \\
\hline 3 & $\begin{array}{c}\text { April } 22 \text { - April 28, } \\
2014\end{array}$ & April 29, 2014 & $\begin{array}{c}\text { April } 30 \text { - May 5, } \\
2014\end{array}$ \\
\hline 4 & $\begin{array}{c}\text { October } 20 \text { - October } \\
24,2014\end{array}$ & October 27,2014 & $\begin{array}{c}\text { October } 28 \text { - } \\
\text { November } 3 \text {, } \\
2014\end{array}$ \\
\hline 5 & $\begin{array}{c}\text { April } 20 \text { - April 24, } \\
2015\end{array}$ & April 27, 2015 & $\begin{array}{c}\text { April } 28 \text { - May 4, } \\
2015\end{array}$ \\
\hline 6 & $\begin{array}{c}\text { October } 22 \text { - October } \\
28,2015\end{array}$ & October 29, 2015 & $\begin{array}{l}\text { October } 31 \text { - } \\
\text { November } 5 \text {, } \\
2015\end{array}$ \\
\hline 7 & $\begin{array}{c}\text { April } 21 \text { - April 27, } \\
2016\end{array}$ & April 28, 2016 & $\begin{array}{l}\text { April 29, } 2016 \text { - } \\
\text { May 5, } 2016\end{array}$ \\
\hline 8 & $\begin{array}{c}\text { October } 20 \text { - October } \\
26,2016\end{array}$ & October 27, 2016 & $\begin{array}{c}\text { October } 28 \text { - } \\
\text { November } 3 \text {, } \\
2016\end{array}$ \\
\hline
\end{tabular}

Source: Indonesia Stock Exchange, Researcher's Data Source

Data analysis was done for each date of Sri Kehati index announcement. On each announcement date, the researchers were examined the market reaction from the abnormal return (AR) and trading volume activity (TVA). Test results for each period of observation presented in the following:

\section{Result of 1st Period Analysis}

The first analysis was conducted for the announcement date of the Sri Kehati index on April 29, 2013. The table below presents the test results for that period as follows:

Table 2 Test of Market Reaction for $1^{\text {st }}$ Periods of Research

\begin{tabular}{lllc}
\hline $\begin{array}{c}\text { Announcement } \\
\text { Date }\end{array}$ & \multicolumn{1}{c}{ Data in Test } & \multicolumn{1}{c}{ Analysis tool } & The p value \\
\hline April 29, 2013 & $\begin{array}{l}\text { AR Before and AR } \\
\text { After }\end{array}$ & $\begin{array}{l}\text { Wilcoxon Signed Rank } \\
\text { Test }\end{array}$ & 0.824 \\
& $\begin{array}{l}\Delta \text { TVA Before and } \\
\Delta \text { TVA After }\end{array}$ & $\begin{array}{l}\text { Wilcoxon Signed Rank } \\
\text { Test }\end{array}$ & 0.643 \\
\hline \multicolumn{2}{c}{ Source: computed by the author }
\end{tabular}

Based on table 2, it was known that both of the abnormal return (AR) and trading volume activity (TVA) tests were showed insignificant results. Testing of abnormal return and trading volume activity (TVA) was showed that there was no significant difference of abnormal return and trading volume activity (TVA) before and after 
announcement of Sri Kehati Index. In testing the index announcement on April $29^{\text {th }}$, 2013, the capital market does not react to the announcement of Sri Kehati index.

\section{Result of 2nd Period Analysis}

The second analysis was conducted for the announcement date of the Sri Kehati index on October 30, 2013. The table below presents the test results for that period as follows:

Table 3 Test of Market Reaction for $2^{\text {nd }}$ Periods of Research

\begin{tabular}{|c|c|c|c|}
\hline $\begin{array}{c}\text { Announcement } \\
\text { Date }\end{array}$ & Data in Test & Analysis tool & $\begin{array}{l}\text { The } p \\
\text { value }\end{array}$ \\
\hline October 30, 2013 & $\begin{array}{l}\text { AR Before and AR } \\
\text { After } \\
\Delta \text { TVA Before and } \\
\Delta \text { TVA After }\end{array}$ & $\begin{array}{l}\text { Wilcoxon Signed } \\
\text { Rank Test } \\
\text { Wilcoxon Signed } \\
\text { Rank Test }\end{array}$ & $\begin{array}{l}0.614 \\
0.499\end{array}$ \\
\hline
\end{tabular}

Table 3 was known that both of the abnormal return and TVA tests were showed insignificant results. The results of the analysis show that there was no significant difference of abnormal return and trading volume activity (TVA) before and after announcement of Sri Kehati Index. In testing the announcement of Sri Kehati index on period of October 30, 2013 was shown that the Indonesian capital market does not react to the announcement of Sri Kehati Index.

\section{Result of 3rd Period Analysis}

The third analysis was conducted for the announcement date of the Sri Kehati index on April 29, 2014. The table below presents the test results for that period as follows:

\section{Table 4 Test of Market Reaction for $3^{\text {rd }}$ Periods of Research}

\begin{tabular}{cllc}
\hline $\begin{array}{c}\text { Announcement } \\
\text { Date }\end{array}$ & \multicolumn{1}{c}{ Data in Test } & \multicolumn{1}{c}{ Analysis tool } & The p value \\
\hline April 29, 2014 & $\begin{array}{l}\text { AR Before and AR } \\
\text { After } \\
\end{array}$ & $\begin{array}{l}\text { Wilcoxon Signed } \\
\text { Rank Test }\end{array}$ & 0.396 \\
& $\Delta$ TVA After & $\begin{array}{l}\text { Wilcoxon Signed } \\
\text { Rank Test }\end{array}$ & 0.700 \\
\hline \multicolumn{2}{c}{ Source: computed by the author }
\end{tabular}

The table 4 was presented the test results for the third observation period of April 29, 2014. Based on the table 4, it was known that both the abnormal return and trading volume activity (TVA) tests were showed insignificant results. The results of the analysis show that there was no significant difference of abnormal return and TVA before and after announcement of Sri Kehati Index. In testing the announcement of the Sri Kehati index on period of April 29, 2014 was shown that the capital market does not react to the announcement of Sri Kehati Index.

\section{Result of 4th Period Analysis}

The fourth analysis was conducted for the announcement date of the Sri Kehati index on October 27, 2014. The table below presents the test results for that period as follows: 
Wijaya, Noviyanti, Mahayu

Table 5 Test of Market Reaction for $4^{\text {th }}$ Periods of Research

\begin{tabular}{|c|c|c|c|}
\hline $\begin{array}{c}\text { Announcement } \\
\text { Date }\end{array}$ & Data in Test & Analysis tool & $\begin{array}{l}\text { The } p \\
\text { value }\end{array}$ \\
\hline October 27, 2014 & $\begin{array}{l}\text { AR Before and AR } \\
\text { After } \\
\Delta \text { TVA Before and } \\
\Delta \text { TVA After }\end{array}$ & $\begin{array}{l}\text { Wilcoxon Signed Rank } \\
\text { Test } \\
\text { Wilcoxon Signed Rank } \\
\text { Test }\end{array}$ & $\begin{array}{l}0.060 \\
0.124\end{array}$ \\
\hline
\end{tabular}

Source: computed by the author

Table 5 was presented the test results for the fourth observation period of October 27, 2014. Based on table 5, it was known that both of the abnormal return and trading volume activity (TVA) tests were showed insignificant results. The results of the analysis show that there was no significant difference of abnormal return and TVA before and after announcement of Sri Kehati index. In testing the announcement of the Sri Kehati index on period of October 27, 2014 was showed that the capital market does not react to the announcement of Sri Kehati index.

\section{Result of 5th Period Analysis}

The fifth analysis was conducted for the announcement date of the Sri Kehati index on April 27, 2015. The table below presents the test results for that period as follows:

Table 6 Test of Market Reaction for $5^{\text {th }}$ Periods of Research

\begin{tabular}{|c|c|c|c|}
\hline $\begin{array}{c}\text { Announcement } \\
\text { Date }\end{array}$ & Data in Test & Analysis tool & $\begin{array}{l}\text { The } \mathrm{p} \\
\text { value }\end{array}$ \\
\hline April 27, 2015 & $\begin{array}{l}\text { AR Before and AR } \\
\text { After } \\
\Delta \text { TVA Before and } \\
\Delta \text { TVA After }\end{array}$ & $\begin{array}{l}\text { Wilcoxon Signed Rank } \\
\text { Test } \\
\text { Wilcoxon Signed Rank } \\
\text { Test }\end{array}$ & $\begin{array}{l}0.967 \\
0.021\end{array}$ \\
\hline
\end{tabular}

Table 6 was presented the test results for the fifth observation period of April 27, 2015. Based on table 6, it was known the abnormal return and trading volume activity (TVA) tests were showed different results. Testing of abnormal return showed insignificant results with $\mathrm{p}$ value of 0.976 . The test results were showed no significant differences in abnormal return before and after the announcement of Sri Kehati index on April 27, 2015. Testing on trading volume activity (TVA) was showed significant results with $p$ value of 0.021 . The test results were shown that there is a significant difference of trading activity volume (TVA) before and after the announcement of Sri Kehati index on April 27, 2015. Abnormal return and trading volume activity (TVA) test was showed inconsistent result to measure market reaction at the announcement of Sri Kehati Index in this period.

\section{Result of 6th Period Analysis}

The sixth analysis was conducted for the announcement date of the Sri Kehati index on October 29, 2015. The table below presents the test results for that period as follows: 
Table 7 Test of Market Reaction for $6^{\text {th }}$ Periods of Research

\begin{tabular}{cllc}
\hline $\begin{array}{c}\text { Announcement } \\
\text { Date }\end{array}$ & \multicolumn{1}{c}{ Data in Test } & Analysis tool & The p value \\
\hline October 29, 2015 & $\begin{array}{l}\text { AR Before and AR } \\
\text { After } \\
\Delta \text { TVA Before and } \\
\Delta \text { TVA After }\end{array}$ & $\begin{array}{l}\text { Wilcoxon Signed } \\
\text { Rank Test } \\
\text { Wilcoxon Signed } \\
\text { Rank Test }\end{array}$ & 0.477 \\
\hline \multicolumn{2}{c}{ Source: computed by the author }
\end{tabular}

Source: computed by the author

Table 7 was presented the test results for the sixth observation period of October 29, 2015. Based on the table above, it was known that the abnormal return and trading volume activity (TVA) tests were showed different results. Testing of abnormal return was showed insignificant results with $\mathrm{p}$ value of 0.477 . The test results were showed that there was no significant difference of abnormal return before and after the announcement of Sri Kehati index on October 29, 2015, Tests on trading volume activity (TVA) was showed significant result with p value of 0.008 . Test results were shown there a significant difference in trading activity volumes (TVA) before and after the Sri Kehati index announcement on October 29, 2015. The abnormal return and trading volume activity (TVA) tests were show inconsistent results for measuring market reaction to the announcement of the Sri Kehati Index of this period. Abnormal return test was showed no significant results while trading volume activity (TVA) test was showed significant results.

\section{Result of 7th Period Analysis}

The seventh analysis was conducted for the announcement date of the Sri Kehati index on April 27, 2016. The table below presents the test results for that period as follows:

Table 8 Test of Market Reaction for $7^{\text {th }}$ Periods of Research

\begin{tabular}{cllc}
\hline $\begin{array}{c}\text { Announcement } \\
\text { Date }\end{array}$ & \multicolumn{1}{c}{ Data in Test } & Analysis tool & The p value \\
\hline April 27, 2016 & $\begin{array}{l}\text { AR Before and AR } \\
\text { After } \\
\Delta \text { TVA Before and } \\
\Delta \text { TVA After }\end{array}$ & $\begin{array}{l}\text { Wilcoxon Signed } \\
\text { Rank Test } \\
\text { Wilcoxon Signed } \\
\text { Rank Test }\end{array}$ & 0.938 \\
\hline \multicolumn{2}{c}{ Source: computed by the author }
\end{tabular}

Source: computed by the author

Table 8 was shown the test results for the seventh observation period of April 27, 2016. Based on the table above, it was known that both of the abnormal return and trading volume activity (TVA) tests were showed insignificant results. The results of the analysis show that there was no significant difference of abnormal return and trading volume activity (TVA) before and after announcement of Sri Kehati Index. In testing the announcement of the Sri Kehati index on period of April 27, 2016 was showed that the capital market did not react to the announcement of Sri Kehati index.

\section{Result of 8th Period Analysis}

The eighth analysis was conducted for the announcement date of the Sri Kehati index on October 27, 2016. The table below presents the test results for that period as follows: 
Wijaya, Noviyanti, Mahayu

Table 9 Test of Market Reaction for $8^{\text {th }}$ Periods of Research

\begin{tabular}{cllc}
\hline $\begin{array}{c}\text { Announcement } \\
\text { Date }\end{array}$ & \multicolumn{1}{c}{ Data in Test } & Analysis tool & The p value \\
\hline October 27, 2016 & $\begin{array}{l}\text { AR Before and AR } \\
\text { After } \\
\begin{array}{l}\Delta \text { TVA Before and } \\
\Delta \text { TVA After }\end{array}\end{array}$ & $\begin{array}{l}\text { Wilcoxon Signed } \\
\text { Rank Test } \\
\text { Wilcoxon Signed } \\
\text { Rank Test }\end{array}$ & 0.278 \\
\hline
\end{tabular}

Source: computed by the author

Table 9 was shown the test results for the seventh observation period of October 27, 2016. Based on table 9, it was known that both of the abnormal return and trading volume activity (TVA) tests were showed insignificant results. Testing of abnormal return and TVA were showed that there was no significant difference of abnormal return and TVA before and after announcement of Sri Kehati index. In testing the announcement of the Sri Kehati index on period of October 27, 2016 was showed that the Indonesian capital market did not react to the announcement of Sri Kehati index.

\section{Discussion}

This research did not succeed in finding fully market reaction to the Sri Kehati Index announcement in Indonesian Stock Exchange. Test market reaction using abnormal returns before and after the announcement date of the Sri Kehati Index shows that there is no significant difference in abnormal returns. The Trading volume activity (TVA) test before and after the announcement of the Sri Kehati index showed there were differences in TVA in the 5th observation period (April 27 2015) and the 6th observation period (October 29, 2015). Test of trading volume activity (TVA) in other observation periods did not show significant results. However, the results of this study support the results of Lindananty and Soedarman's (2015) study which found that the Indonesia Stock Exchange has not reacted consistently to the announcement of the Sri Kehati index.

The researchers were tried explain why the Indonesian Stock Exchange does not consistently respond to the Sri Kehati Index announcement. The Sri Kehati index is information related to sustainable investment with consideration of social and environmental aspects of the company assessed by external parties. Researchers were argued that the company included in the Sri Kehati index consists of 25 companies with various types of industries. There are companies with manufacturing, mining, banking and construction companies in the index winners. At the time of this index was announced of course the condition of each type of industry is not the same. The capital market reaction to information from each industry may not be in line, so when the analysis was carried out in one step for the 25 Sri Kehati index companies, the analysis provided an inconsistent response.

The researcher argues that changes in companies that won the Sri Kehati index in the Indonesian Capital Market did not occur massively. Changes in company data only occur in the initial period of the year in the April announcement period. In general, the announcement of the winner of the Sri Kehati index in the October period was not different from the winner of the Sri Kehati index in the April period of the same year. If analyzed for four years of observation, the company appointed as the winner of the Sri Kehati Index did not experience many changes. There is only one until three companies that remain and leave the winning data index. This caused the capital market to no longer react to the announcement of the Sri Kehati index. The announcement of the Sri Kehati index did not cause a shocking effect on the capital market, so the 
Indonesian Stock Exchange did not react to the announcement of the Sri Kehati index in this study.

\section{Conclusions and Recommendations}

This study concluded that the results of the abnormal return test before and after the announcement of the Sri Kehati Index did not provide significantly different results. The results of the trading volume activity test (TVA) show that at the eight dates of the announcement of the Sri Kehati index there were two testing periods which showed differences in TVA that occurred in the 5th and 6th period. In the other six periods there was no difference between the volume of stock trading (TVA) before and after the announcement of the Sri Kehati Index on the Indonesia Stock Exchange. Overall this study concluded that the Indonesia Stock Exchange did not consistently react to the announcement of the Sri Kehati index.

This research cannot be separated from limitations. The limitation of this study is that testing the market reaction to the Sri Kehati index is carried out for all data without considering the type of industry. Companies that are included in the winners of the Sri Kehati Index consist of 25 companies with various types of industries. This condition can cause different reactions by market players depending on the conditions of each type of industry.

Further research is recommended to distinguish the market reaction test from the announcement of the Sri Kehati index based on each type of industry. Further research is also recommended to test the announcement of other events in the Indonesian capital market such as the CSR award announcement.

\section{References}

Asmara, E.N. (2015), Pengaruh Karakteristik Perusahaan terhadap Reaksi Pasar Modal: Studi Empiris pada Perusahaan yang termasuk dalam Indeks Sri-Kehati Tahun 2009-2011, Jurnal EBBANK, 8 (1), 17-32.

Astuti, C.W., Nugrahati, Y.W. (2015), Pengaruh Pengungkapan Corporate Social Responsibility terhadap Reaksi Pasar, Dinamika Akuntansi, Keuangan dan Perbankan, 4 (2), 90-105.

Beaver, W.H. (1968), The Information Content of Annual Earnings Announcements, Journal of Accounting Research Supplement, 6 (3), 67-92.

Becchetti, L., Solferino, N., Tessitore, M.E. (2014), Corporate social responsibility and profit volatility: theory and empirical evidence, Industrial and Corporate Change, 25 (1), 49-89.

Cahan, S.F., Charl, D.V., Debra, J.T., Vic, N., Chris, J.V.S. (2016), Are CSR Disclosures Value Relevant? Cross-Country Evidence, European Accounting Review, 25 (3), 579-611.

Carnevale, C., Maria, M., Sergio, V. (2012), Corporate Social Reporting in European Banks: The Effects on a Firm's Market Value, Corporate Social Responsibility and Environmental Management, 19 (1), 159-177.

Cheng, M., Christiawan, Y.C. (2011), Pengaruh Pengungkapan Corporate Social Responsibility terhadap Abnormal Return, Jurnal Akuntansi dan Keuangan, 13 (1), 24-36.

Du, S., Yu, K., Bhattacharya, C.B., Sen, K. (2017), The Business Case for Sustainability Reporting: Evidence from Stock Market Reactions, Journal of Public Policy \& Marketing, 36 (2), 313-330.

Halkos, G., Sapetis, A. (2007), Can Capital Markets Respond to Environmental Policy Of Firms? Evidence from Greece, Ecological Economics, 63 (1), 578-587. 
Indahyati, S.N, Wijaya, A.L. (2014), Kemampuan Komponen Laba dalam Memprediksi Laba Masa Depan, Assets: Jurnal Akuntansi dan Pendidikan, 3 (2), 75-87.

Kusumaningtyas, T.K, Andayani (2015), Pengaruh Good Corporate Governance terhadap Nilai Perusahaan yang Terdaftar pada Indeks Sri-Kehati, Jurnal Ilmu \& Riset Akuntansi, 4 (7), 1-15.

Kziezak, P., Fincbach, B. (2017), Triple Bottom Line: The Pillars of CSR, Journal of Corporate Social Responsibility and Leadership, 4 (3), 95-110.

Laurensia, S. (2015), Pengaruh Kinerja Keuangan terhadap Harga Saham Melalui Pengungkapan CSR pada Perusahaan Konstituen Indeks Sri Kehati, AGORA, 3 (2), 491-497.

Lopatta, K., Frerich, B., Thomas, K. (2016), Asymmetric Information and Corporate Social Responsibility, Bussines \& Society, 55 (3), 458-488.

Lyndananti, Soedarman, M. (2015), Konsistensi Reaksi Pasar Modal Indonesia terhadap Penerbitan Indeks Sri-Kehati, Jurnal Manajemen dan Kewirausahaan, 7 (1), 43-54.

Malik, M.S., Kanwal, L. (2018), Impact of Corporate Social Responsibility Disclosure on Financial Performance: Case Study of Listed Pharmaceutical Firms of Pakistan, Journal of Business Ethics, 150 (1), 69-78.

Ramiah, V., Belinda, M., Imad, M. (2013), How does The Stock Market React to The Announcement of Green Policies?, Journal of Banking \& Finance, 37 (1), 17471758 .

Reddy, R.R., Kalla, K. (2018), Corporate Social Responsibility: Conceptual Framework, International Journal of Research in Commerce and Management, 9 (2), 30-35.

Wang, H., Li, T., Riki, T., Gerard, G. (2016), Corporate Social Responsibility: an Overview and New Research Directions, Academy of Management Journal, 59 (2), 534-544.

Wang, K.T., Li, D. (2016), Market Reactions to the First-Time Disclosure of Corporate Social Responsibility Reports: Evidence from China, Journal of Business Ethics, 136 (1), 661-682.

Wijaya, M.S., Sudana, I.P. (2017), Pengaruh Sustainability Report pada Reaksi Pasar dengan Kinerja Keuangan sebagai Variabel Kontrol, E-Jurnal Akuntansi Universitas Udayana, 21 (1), 616-642.

Zulkafli, A.B., Zamri, A., Eky, E.M. (2017), The Performance of Socially Responsible Investments in Indonesia: A Study of the Sri Kehati Index (SKI), Gadjah Mada International Journal of Business, 19 (1), 59-76.

https://www.idx.co.id/

https://kehati.or.id/indeks-sri-kehati/ 